\title{
VANILLIN EXTRACTED FROM PROSO MILLET AND BARNYARD MILLET INDUCE APOPTOSIS IN HT-29 AND MCF-7 CELL LINE THROUGH MITOCHONDRIA MEDIATED PATHWAY
}

\author{
DEEPA PRIYA RAMADOSS, NAGESWARAN SIVALINGAM* \\ Department of Biotechnology, School of Bioengineering, SRM University, Kattankulathur, Kancheepuram - 603 203, Tamil Nadu, India. \\ Email: nageswaran.s@ktr.srmuniv.ac.in
}

Received: 03 July 2017, Revised and Accepted: 03 August 2017

ABSTRACT

Objective: The main aim of the study was to investigate the bioactive compound vanillin extracted from proso millet (compound 1), and barnyard millet (compound 2) induces apoptotic cell death and whether it is mediated through mitochondrial pathway in HT-29 and MCF-7 cell line.

Methods: The cells were treated with $250 \mu \mathrm{g} / \mathrm{ml}$ and $1000 \mu \mathrm{g} / \mathrm{ml}$ concentration of extracted vanillin for $48 \mathrm{hrs}$. Cytochrome c release and expression level of pro-apoptotic protein Bax and caspase-9 were detected by western blot analysis.

Results: The results reveal that extracted compounds increased the release of cytochrome $\mathrm{c}$ and upregulating the expression of Bax and caspase-9 as concentration increases in a dose-dependent manner.

Conclusion: The study suggests that the vanillin compound extracted from these millets induces apoptotic cell death through a mitochondriadependent pathway.

Keywords: Proso millet, Barnyard millet, Vanillin, HT-29 cells, MCF-7 cells, Cytochrome c, Bax, Caspase-9.

(C) 2017 The Authors. Published by Innovare Academic Sciences Pvt Ltd. This is an open access article under the CC BY license (http://creativecommons. org/licenses/by/4. 0/) DOI: http://dx.doi.org/10.22159/ajpcr.2017.v10i12.21088

\section{INTRODUCTION}

Cancer is one of the most leading sources of death in both developing and developed countries and sustains to be a main community health problem in various parts of the world [1]. Cancer is one of the most life-threatening diseases [2] with an uncontrolled growth and spread as atypical cells and related with a programmed cell death, dysregulation of apoptosis [3]. World cancer report released by the International Agency for Research on Cancer States that worldwide there were 7.6 million of deaths and 12.4 million of new cancer cases in both males and females [4]. Nowadays, cancer treatments such as surgery, radiation, and chemotherapeutic agents have not completely effective against the low or high survival incidence of most of the cancers [5]. In the area of cancer chemoprevention, the new anticancer drugs developed from foods or plant sources is one of the most prominent and auspicious approaches and this led to the detection of several novel anticancer drugs [6].

More than thousands of year human have trusted the natural products as the most productive origin of medicines and leads for drug development [7]. In several countries especially in India, China, and Egypt, the traditional medication systems were designed based on the plant-based natural product. In recent years, natural product and imitative from the natural product as a new anticancer drug and antibiotics are permitted by US Food and Drug Administration (FDA) [8-10]. Natural products mostly from plant source have an important basis for discovering new bioactive components with few side effects and high efficacy [11]. Anticancer properties have been revealed against a broad range of cancers by numerous foods, for example, grains, cereals, spices, vegetables, and medicinal plants and their bioactive compounds [12].

Many literature studies have stated that mechanism of action of anticancer drugs is based on apoptosis induction, and it initiated a new approach for searching anticancer drug [13]. Several cancer chemical drugs have induced apoptosis to neglect cancer cells and in which cells die is due to physiological process [14]. Apoptosis is a programmed cell death; it is important for normal cell mechanism. The relationship between cancer and apoptosis has been highlighted with numerous evidence proposing that correlated the processes of transformation progression and metastasis implicate the modification of normal apoptotic pathways. Apoptosis is severely regulated pathway responsible for damaged cells. It not only signifies an effective mechanism of elimination of harmful cells but it also plays an important role in the growth and maintenance of tissue homeostasis [15]. The main typical feature of the apoptosis pathway was mitochondrial dysfunction [16].

Vanillin (4-hydroxy-3-methoxybenzaldehyde) is a naturally occurring bioactive compound found in the pods of Vanilla spp., and also found in many plant species consuming various properties. It is one of the most extensively used flavoring agents in food and personal products [17]. Over past 20 years, there has been an increasing attention in using vanillin as an antimutagenic agent [18]. Based on the relationship among antimutagenic and anticarcinogenic activities, it was liable that vanillin presents anticarcinogenic effect [19]. Vanillin has potential antioxidant and antitumor properties [20], and it was reported that its activity was more beneficial for regular health care [21]. Cheng et al. found that vanillin significantly alter gene expression in the human hepatocellular carcinoma cell line HepG2 [17] and Lirdprapamongkol et al. reported that vanillin suppresses the in vitro invasion and in vivo migration of mammary adenocarcinoma cancer cells [22]. In our previous studies, it was confirmed that extracted vanillin compound have effectively induced apoptotic cell death. Intrinsic and extrinsic signaling pathways are variable in different types of cells. The exact mechanism of vanillin induced apoptosis in HT-29 and MCF-7 cells is still unknown. Hence, in this study, we investigate the molecular mechanism of apoptosis induced by vanillin compound extracted from 
proso and barnyard millet in human colon cancer cell line (HT-29) and human breast cancer cell line (MCF-7).

\section{METHODS}

Plant material and extraction of compounds

Dried seeds of Proso millet (PM) (CO(PV)5) and Barnyard millet (BM) $(\mathrm{CO}(\mathrm{KV}) 2)$ were purchased and authenticated from the Department of Millet, Tamil Nadu Agriculture University, Coimbatore, Tamil Nadu, India. Bioactive compounds were extracted by supercritical fluid extraction system. The structure of the extracted bioactive compounds from PM and BM were elucidated using spectroscopic methods (ultraviolet, infrared [IR], liquid chromatography-mass spectrometry [LC-MS], and ${ }^{1} \mathrm{H}$-and ${ }^{13} \mathrm{C}$-nuclear magnetic resonance [NMR]).

\section{Cell culture}

HT-29 human colon cancer cells and MCF-7 human breast cancer cell line were purchased from National Centre for Cell Sciences, Pune, India. The cells were cultured and maintained in McCoy's 5A medium for HT-29 and Dulbecco's modified Eagle's medium for MCF-7 supplemented with $10 \%$ heat-inactivated fetal bovine serum and $10,000 \mathrm{IU} / \mathrm{ml}$ penicillin $\mathrm{G}$, $10 \mathrm{mg} / \mathrm{ml}$ streptomycin, and $25 \mu \mathrm{g} / \mathrm{ml}$ amphotericin. The cells were maintained at $37^{\circ} \mathrm{C}$ in a humid of $5 \% \mathrm{CO}_{2}$ incubator. The experiments were performed when the cells reach $80 \%$ confluence. For in vitro molecular studies, cells were seeded in a $100 \mathrm{~mm}$ sterile plate for Western blotting and incubated in $5 \% \mathrm{CO}_{2}$ incubator for $24 \mathrm{hrs}$ at $37^{\circ} \mathrm{C}$. The cells were treated with $250 \mu \mathrm{g} / \mathrm{ml}$ and $1000 \mu \mathrm{g} / \mathrm{ml}$ concentration of extracted compounds and incubated for $48 \mathrm{hrs}$, and analysis was performed. The dimethyl sulfoxide treated cells served as control.

\section{Preparation of cell lysate}

HT-29 cells and MCF-7 cells were seeded at a density of $1 \times 10^{7}$ cells $/ 100 \mathrm{~mm}$ Petri dish and grown for $24 \mathrm{hrs}$. The cells were treated with $250 \mu \mathrm{g} / \mathrm{ml}$ and $1000 \mu \mathrm{g} / \mathrm{ml}$ concentration of extracted compounds (1 and 2) from PM and BM and incubated for $48 \mathrm{hrs}$. After $48 \mathrm{hrs}$ treatment, the medium was aspirated, and cell culture plate was placed on the ice and washed twice with ice-cold phosphate buffer saline (PBS). Drained the PBS and the cells were lysed by added $250 \mu \mathrm{l}$ lysis buffer (NP-40 buffer-150 mM NaCl, $50 \mathrm{mM}$ Tris, pH 8.0, and $1 \%$ NP-40) containing protein inhibitor cocktail. The cells were scraped from the plate using cold plastic cell scraper and gently transferred the cell suspension into the pre-cooled centrifuge tubes. The tubes were kept on ice for 30 minutes with constant agitation. The lysates were centrifuged at 12,000 rpm for 20 minutes at $4^{\circ} \mathrm{C}$ and collected the supernatant to the new tubes and stored at $4^{\circ} \mathrm{C}$ until sodium dodecyl sulfate-polyacrylamide gel (SDS-PAGE) analysis [23].

\section{Lactate dehydrogenase (LDH) assay}

LDH catalyzes the oxidation of lactate to pyruvate in the presence of coenzyme NAD+. The measurement of the amount of LDH released from cells is one of the key methods to evaluate the cytotoxic cell death [24]. After treating the cells with $250 \mu \mathrm{g} / \mathrm{ml}$ and $1000 \mu \mathrm{g} / \mathrm{ml}$ concentration of extracted compounds for $48 \mathrm{hrs}$. The medium was aspirated and centrifuged at $300 \mathrm{~g}$ for 5 minutes, and the supernatant was collected to measure the LDH activity. Briefly, $50 \mu \mathrm{l}$ of cell culture medium was added to $2 \mathrm{ml}$ of Tris-EDTA-NADH buffer and incubated at $37^{\circ} \mathrm{C}$ for 15 minutes. After incubation, $200 \mu \mathrm{l}$ of pyruvate was added, and immediately optical density was measured at $339 \mathrm{~nm}$ for 3 minutes at a time interval of 15 seconds.

\section{Western blot analysis}

The total protein concentration was estimated using Bradford method with bovine serum albumin (BSA) used as a standard. The equal amount of proteins $(75 \mu \mathrm{g} / \mathrm{ml})$ from each sample was reconstituted with $3 \times$ Laemmli sample buffer $(0.1875 \mathrm{M}$ Tris- $\mathrm{HCl}, 6 \%$ SDS, $15 \%$ 2-mercaptoethanol, 30\% glycerol, $0.006 \%$ bromophenol blue, and $\mathrm{pH} 6.8$ ) and the mixture was boiled at $90^{\circ} \mathrm{C}$ for 5 minutes. The denatured proteins were separated on 15\% SDS-PAGE followed by transferring the protein in the gel onto the polyvinylidene difluoride membranes by wet blotting transfer at $80 \mathrm{~V}, 200 \mathrm{~mA}$ for $2.5 \mathrm{hrs}$. The membranes were washed and blocked with $5 \%$ BSA in tris-buffered saline containing $0.1 \%$ Tween-20 (TBST) for $2 \mathrm{hrs}$ at room temperature. Moreover, membranes were incubated with primary antibodies anti-Bax (1:2000 dilution), caspase-9 (1:1000 dilution), and cytochrome c (1:1000 dilution) for an overnight on a rocker at $4^{\circ} \mathrm{C}$. Then, the membrane washed thrice in TBST for 5 minutes each, followed by incubating the membrane in horseradish peroxide-conjugated secondary antibody (1:5000 dilution) for $1.5 \mathrm{hrs}$ at room temperature. After incubation over, the membrane was washed thrice in TBST. Then, the membrane was developed using Bio-Rad Clarity Max" western ECL blotting substrate and visualized in Chemidoc (Bio-Rad Molecular Imager ChemiDoc XRS + Imaging System, California, USA). Then, the blot was stripped using stripping buffer (Tris- $\mathrm{HCl}, 10 \%$ SDS, 2-mercaptoethanol) at $50^{\circ} \mathrm{C}$ for 30 minutes. After washing with TBST thrice, the same blot was used to probe for the next protein [25].

\section{Statistical analysis}

All the experiments were done in triplicates and mean data values are expressed as their deviation as mean $\pm \mathrm{SD}$, and all data were analyzed by two-way analysis of variance (ANOVA) using GraphPad Prism 5 software to determine the significant differences between the groups. $\mathrm{p}<0.05$ was considered to be significant, *indicates a significant result when compared with control $(\mathrm{p}<0.05)$.

\section{RESULTS AND DISCUSSION}

The bioactive compounds extracted from PM and BM using supercritical fluid extraction method. The extracted compounds structure was elucidated using spectroscopic methods (LC-MS, IR, ${ }^{1} \mathrm{H}$ - and ${ }^{13} \mathrm{C}$-NMR). Based on these spectroscopic results it was identified that bioactive component extracted from PM (compound 1) and BM (compound 2) was found to be a phenolic aldehyde-vanillin (4-hydroxy-3-methoxybenzaldehyde) (data not shown). LDH assay results confirm that extracted compound vanillin efficiently induces noncytotoxic cell death which implies that it might be intermediated through induction of apoptosis in HT-29 and MCF-7 cells (data not shown).

Apoptosis plays a key role in the treatment of cancer and oncogenesis. It removes extra unwanted or damaged cells and is a regulated pathway mainly for maintaining homeostasis in multicellular organisms. It can be triggered by numerous internal and external signals. These signaling pathways are controlled by the expression of apoptosis-related proteins [26]. There are two groups of proteins involved in regulation of apoptosis are anti-apoptotic and pro-apoptotic proteins [27]. In our previous study, it was confirmed that compound 1 and 2 induce apoptotic cell death at the concentration of $250 \mu \mathrm{g} / \mathrm{ml}$ and $1000 \mu \mathrm{g} / \mathrm{ml}$ for $48 \mathrm{hrs}$. In this study, we explicate the possible mechanism through which extracted compounds induce apoptotic cell death in HT-29 and MCF-7 cells. The cells were treated with $250 \mu \mathrm{g} / \mathrm{ml}$ and $1000 \mu \mathrm{g} / \mathrm{ml}$ concentration of extracted compound from PM and BM for 48 hrs. The changes in the expression level of the protein that might be involved in compounds induce apoptotic cell death was observed in western blotting.

Effect of extracted compound vanillin from PM and BM on cytochrome c release

Cytochrome $\mathrm{c}$ is main signaling molecule of apoptosis which translocates from mitochondria into the cytosol of many cell types undergoing mitochondria-dependent apoptosis [25]. Cytochrome $\mathrm{c}$ is the proapoptotic signal molecules which can initiate the reaction of the caspase cascade and induce the apoptosis in the end [28]. After treating HT29 and MCF-7 cells for $48 \mathrm{hrs}$ with a concentration of $250 \mu \mathrm{g} / \mathrm{ml}$ and $1000 \mu \mathrm{g} / \mathrm{ml}$ of compound 1 and 2 . It enhances the release of cytochrome c from mitochondria. The expression level of cytochrome $\mathrm{c}$ release was significantly increased in both the cell lines in a dose-dependent manner when compared with control (Figs. 1a and b, 2b).

Effect of extracted compound vanillin from PM and BM on expression of Bax and caspase-9

In the mitochondrial pathway of apoptosis, several signaling molecules can cause the alterations in mitochondrial membrane permeability 
transition and mitochondrial membrane potential resulting in the release of cytochrome c [29]. Mitochondrial initiated cytochrome c release is directly assisted by Bax [30]. Bax is a pro-apoptotic member of Bcl-2 family important for apoptosis. It could be responsible for these mitochondrial changes and activation of caspase both in vitro and in vivo during apoptosis [31]. The changes in the expression of the pro-apoptotic protein Bax that might be involved in extracted compound induce cell death was detected by western blotting. As

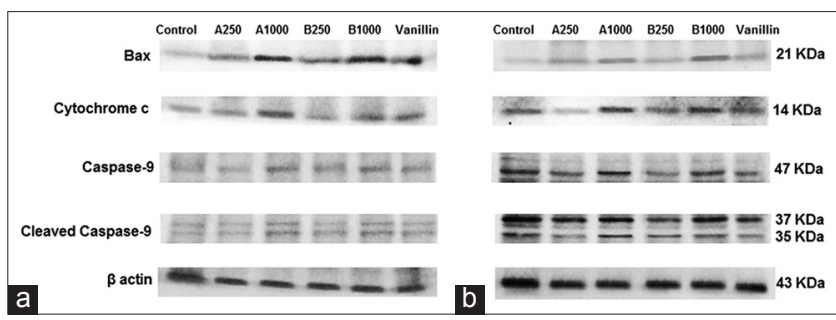

Fig. 1: Effect of extracted vanillin compounds on expression of pro-apoptotic protein Bax, caspase- 9 and cytochrome $\mathrm{c}$ release in HT-29 cells and MCF-7 cells. (a) HT-29 cells were treated with $250 \mu \mathrm{g} / \mathrm{ml}$, and $1000 \mu \mathrm{g} / \mathrm{ml}$ for $48 \mathrm{hrs}$ and protein expression level was detected. (b) MCF-7 cells were treated with $250 \mu \mathrm{g} / \mathrm{ml}$, and $1000 \mu \mathrm{g} / \mathrm{ml}$ for $48 \mathrm{hrs}$ and protein expression level was detected. Protein $(75 \mu \mathrm{g} / \mathrm{ml})$ from each sample was resolved on $15 \%$ sodium dodecyl sulfate-polyacrylamide gel and western blot performed. $\beta$ actin is a housekeeping protein used as a positive loading control in all experiments. The result from three independent experiments is shown. Where, $A$ - proso millet (A250, A1000) and B - barnyard millet (B250, B1000) shown in Figs. 1a and $2 \mathrm{~b}$ the result indicates that on the $48 \mathrm{hrs}$ treatment of extracted compound 1 and 2 in HT-29 and MCF-7 cell line, the expression level of Bax was dose-dependently up-regulated in colon cancer cell line. Similarly in MCF-7 cell line expression level of Bax was also up-regulated (Figs. 1b and 2a). Therefore, the effect of compounds (1 and 2) on inducing apoptosis in HT-29 and MCF-7 cells might be related to the upregulation of the $\mathrm{Bcl}-2$ family proteins.

Caspase-9 is one of the key initiator caspases and an important member of the caspase (cysteine-aspartic acid protease) family. Caspase- 9 was activated during programmed cell death. On apoptotic activation, cytochrome $\mathrm{c}$ released from mitochondria linked with the pro-caspase and facilitate stimulation of caspase $9(47 \mathrm{kDa})$ involves in proteolytic processing resulting into two subunits at 35 and $37 \mathrm{kDa}$. These subunits attend to increase the apoptotic response. In addition, the cleaved caspase- 9 processes other members of caspase (caspase- 3 and caspase-7) to initiate a caspase cascades which leads to the apoptosis. To study, whether the extracted compounds initiate the apoptosis through a caspase-dependent pathway. HT-29 and MCF-7 cell lines were treated for $48 \mathrm{hrs}$ with $250 \mu \mathrm{g} / \mathrm{ml}$ and $1000 \mu \mathrm{g} / \mathrm{ml}$ concentration of compound 1 and 2.. Fig. 1a and b show that the expression levels of caspase-9 were significantly up-regulated (Fig. 2c) and activated the cleaved caspase-9 (p35 and p37 subunit) as concentration increases in a dose-dependent manner (Figs. 1a and b, 2d and e). On various cancer cell lines that might prompt apoptosis through translocation of Bax that activate caspase to induce apoptosis [32]

In previous studies, vanillin considered as a safe compound for use in food and drug by the FDA based on the LD50 oral vanillin concentration in rats $(1.58-2.8 \mathrm{~g} / \mathrm{kg})$ [33]. Ho et al. (2009) stated that profile of gene expression was assessed in vanillin treated HepG2 cell line.

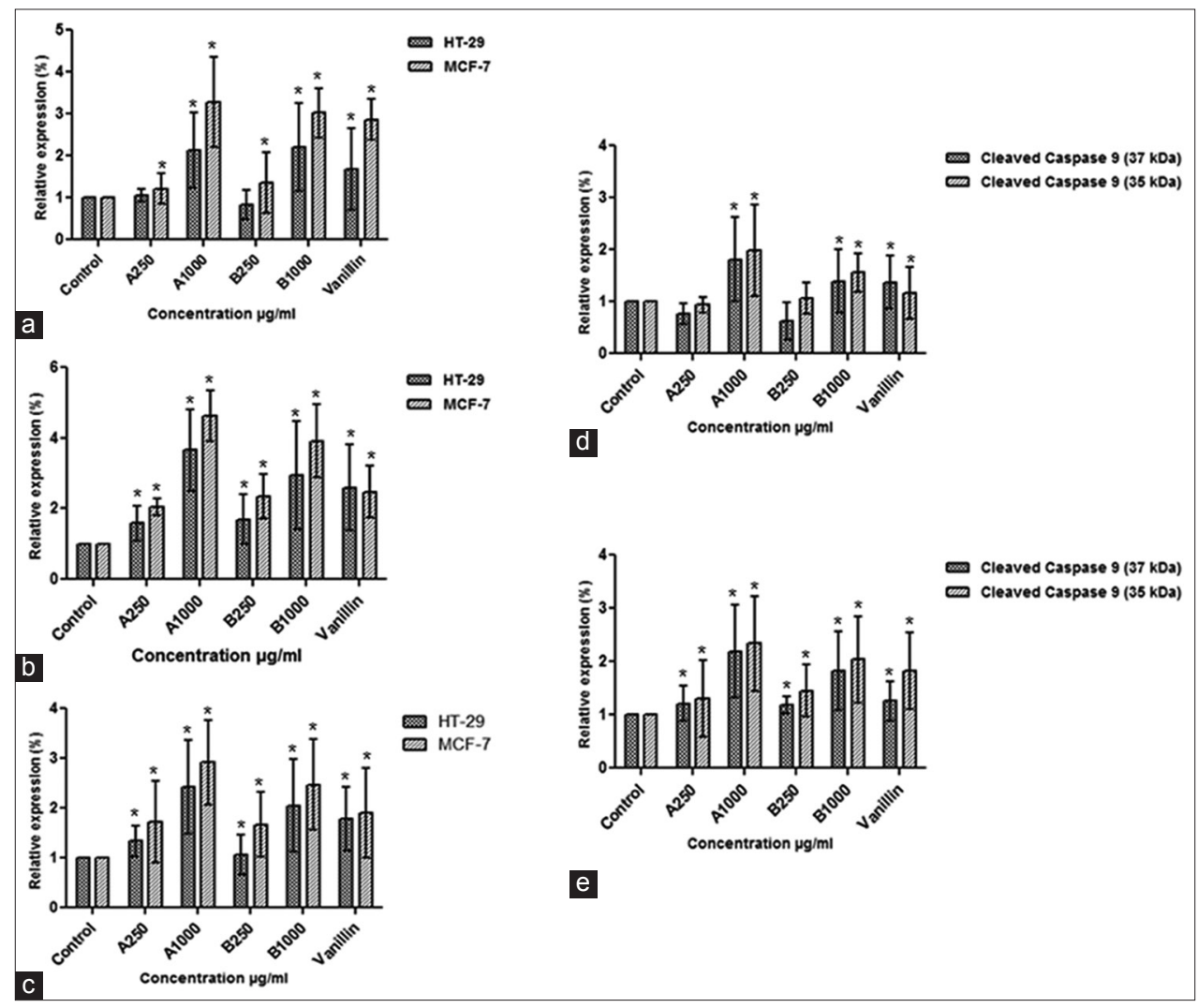

Fig. 2: Bar chart is representing the expression level of apoptotic protein Bax, caspase-9 and cytochrome c quantified by densitometric analysis. (a) The expression level of Bax in HT-29 and MCF-7 cell line. (b) The expression level of cytochrome c release in HT-29 and MCF-7 cell line. (c) The expression level of caspase-9 in HT-29 and MCF-7 cell line. (d and e) The expression level of cleaved caspase-9 in HT-29 and MCF-7 cell line, respectively. Where, A - proso millet (A250, A1000) and B - barnyard millet (B250, B1000). The expressions of all the protein were quantified with respect to the expression of $\beta$ actin. Values are expressed as a mean \pm standard deviation from three independent experiments. *Indicates a significant result when compared with control $(p<0.05)$ 
Downregulating genes by vanillin are categories in three groups they are cell cycle, regulation of cellular process and cell death. Most of the down-regulated genes were related to cancer development. Vanillin inhibits AP-1 protein activity by decreasing the phosphorylation of ERK (extracellular signal-regulated protein kinase), this specifying that vanillin-regulated AP-1 activity through the ERK pathway [17]. In addition, Deb et al. (2011) postulated that vanillin enhanced tumor necrosis factor-related apoptosis-inducing ligand inducing cell death through NF- $\mathrm{KB}$ activation [22]. In HT-29 cells vanillin induce both cytolytic and cytostatic effects which led to cell death through apoptosis pathway [18]. Our results reported for the first time that vanillin compound extracted from PM and BM induced apoptotic cell death through mitochondria mediated pathway. The expression of Bax, caspase 9 protein and cytochrome c release was up-regulated in HT-29 and MCF-7 cells in a concentration dependent manner through apoptotic signaling pathway.

\section{CONCLUSION}

Our results reveal for the first time that molecular mechanism of extracted compound vanillin from PM and BM significantly induces apoptotic cell death in human colon cancer cell line (HT-29) and human breast cancer cell line (MCF-7) through apoptotic signaling pathway. During apoptosis processes, extracted compounds increased the release of cytochrome $\mathrm{c}$ and upregulating the expression level of Bax and caspase- 9 as concentration increases in a dose-dependent manner. From these outcomes, it was concluded that vanillin compound induces apoptosis in HT-29 and MCF-7 cells show that vanillin can be used as an effective chemotherapeutic agent. Further, it is necessary to identify whether this millet consumption will have an effect on colon and breast cancer control in an in vivo animal model.

\section{ACKNOWLEDGMENT}

The authors would like to acknowledge the Department of Biotechnology, School of Bioengineering, SRM University, Kattankulathur 603203, Tamil Nadu, India, for the financial support.

\section{REFERENCES}

1. Jemal A, Siegel R, Xu J, Ward E. Cancer statistics, 2010. CA Cancer J Clin 2010;60(5):277-300.

2. El-Hafeez AA, Rakha OM. Paederus alfieri extract induces apoptosis in human myeloid leukemia K562 Cells. Asian J Pharm Clin Res 2017;10:70-3

3. Sumalatha D, Nithya TG. In vitro anti-oxidant and anticancer activity of Murraya koenigii against human colon cancer HT-29 cell lines. Asian J Pharm Clin Res 2014;7:83-6.

4. Boyle P, Levin B. World cancer report 2008. Cancer Control 2008;199:12-497.

5. Moongkarndi P, Kosem N, Kaslungka S, Luanratana O, Pongpan N, Neungton N. Antiproliferation, antioxidation and induction of apoptosis by Garcinia mangostana (mangosteen) on SKBR3 human breast cancer cell line. J Ethnopharmacol 2004;90(1):161-6.

6. Cragg GM, Newman DJ. Plants as a source of anti-cancer agents. J Ethnopharmacol 2005;100(1-2):72-9.

7. Harvey AL. Natural products as a screening resource. Curr Opin Chem Biol 2007;11(5):480-4.

8. Harvey A. Strategies for discovering drugs from previously unexplored natural products. Drug Discov Today 2000;5(7):294-300.

9. Babak E, Yari KY, Ali AM, Rahmani S, Rahimi M, Amanlou M. Anticariogenic properties of malvidin-3,5-diglucoside isolated from Alcea longipedicellata against oral bacteria. Int J Pharmacol 2007;3:468-74.

10. Newman DJ, Cragg GM. Natural products as sources of new drugs over the last 25 years. J Nat Prod 2007;70(3):461-77.

11. Neerugatti DB, Battu GR, Bandla R. Cytotoxicity activity of some Indian medicinal plants. Int J Curr Pharm Res 2016;8:86-8.
12. Rajamanickam S, Agarwal R. Natural products and colon cancer: Current status and future prospects. Drug Dev Res 2008;69(7):460-71.

13. Ramasamy S, Abdul Wahab N, Zainal Abidin N, Manickam S, Zakaria Z. Growth inhibition of human gynecologic and colon cancer cells by Phyllanthus watsonii through apoptosis induction. PLoS One 2012;7(4): e34793.

14. Sepehr S, Sepehri H, Khodagholi F, Delphi L. Apple pectin (AP) induced apoptosis via nitric oxide (NO) in human prostate cancer cells du145. Int J Pharm Pharm Sci 2015;7:281-5.

15. Yang HL, Chen CS, Chang WH, Lu FJ, Lai YC, Chen CC, et al. Growth inhibition and induction of apoptosis in MCF-7 breast cancer cells by Antrodia camphorata. Cancer Lett 2006;231(2):215-27.

16. Regina AO, Asante IK, Safo DO, Tuffour I, Ofori-Attah E, Uto T, et al. Cytotoxic effects of Albizia zygia (DC) JF Macbr, a Ghanaian medicinal plant, against human T-lymphoblast-like leukemia, prostate and breast cancer cell lines. Int $\mathrm{J}$ Pharm Pharm Sci 2016;8:392-6.

17. Cheng WY, Hsiang CY, Bau DT, Chen JC, Shen WS, Li CC, et al. Microarray analysis of vanillin-regulated gene expression profile in human hepatocarcinoma cells. Pharmacol Res 2007;56(6):474-82.

18. Ho K, Yazan LS, Ismail N, Ismail M. Apoptosis and cell cycle arrest of human colorectal cancer cell line HT-29 induced by vanillin. Cancer Epidemiol 2009;33(2):155-60.

19. Bezerra DP, Soares AK, de Sousa DP. Overview of the role of vanillin on redox status and cancer development. Oxid Med Cell Longev 2016;2016:9734816.

20. Pedroso LS, Fávero GM, de Camargo LE, Mainardes RM, Khalil NM. Effect of the o-methyl catechols apocynin, curcumin and vanillin on the cytotoxicity activity of tamoxifen. J Enzyme Inhib Med Chem 2013;28(4):734-40.

21. Tai A, Sawano T, Yazama F, Ito H. Evaluation of antioxidant activity of vanillin by using multiple antioxidant assays. Biochim Biophys Acta 2011;1810(2):170-7.

22. Lirdprapamongkol K, Sakurai H, Kawasaki N, Choo MK, Saitoh Y, Aozuka Y, et al. Vanillin suppresses in vitro invasion and in vivo metastasis of mouse breast cancer cells. Eur J Pharm Sci 2005;25(1):57-65.

23. Harlow ED, Lane D. Using Antibodies: Cold Spring Harbor. New York: Cold Spring Harbor Laboratory Press; 1999.

24. Moss DW, Henderson AR. Determination of lactate dehydrogenase activity by measurement of NADH consumption. In: Carl AB, Edward RA, editors. Tietz Text Book of Clinical Chemistry. $2^{\text {nd }}$ ed. Philadelphia, PA: W.B. Saunders Company; 1994. p. 816-8.

25. Wang JB, Qi LL, Zheng SD, Wu TX. Curcumin induces apoptosis through the mitochondria-mediated apoptotic pathway in HT-29 cells. J Zhejiang Univ Sci B 2009;10(2):93-102.

26. Lay MM, Karsani SA, Malek SN. 1-(2,6-dihydroxy-4-methoxyphenyl)2-(4-hydroxyphenyl) ethanone-induced cell cycle arrest in G1/G0 in HT-29 cells human colon adenocarcinoma cells. Int J Mol Sci 2014;15(1):468-83.

27. Reed JC, Pellecchia M. Apoptosis-based therapies for hematologic malignancies. Blood 2005;106(2):408-18.

28. Hongme Z. Extrinsic and intrinsic apoptosis signal pathway review scientist. Apoptosis and medicine. Intech Open 2012;2:3-22.

29. Deckwerth TL, Elliott JL, Knudson CM, Johnson EM Jr, Snider WD, Korsmeyer SJ. BAX is required for neuronal death after trophic factor deprivation and during development. Neuron 1996;17(3):401-11.

30. Martinou I, Desagher S, Eskes R, Antonsson B, André E, Fakan S, et al. The release of cytochrome c from mitochondria during apoptosis of NGF-deprived sympathetic neurons is a reversible event. J Cell Biol 1999;144(5):883-9.

31. Finucane DM, Bossy-Wetzel E, Waterhouse NJ, Cotter TG, Green DR. Bax-induced caspase activation and apoptosis via cytochrome $\mathrm{c}$ release from mitochondria is inhibitable by Bcl-xL. J Biol Chem 1999;274(4):2225-33.

32. Da'i M, Anti S, Edi M, Umar AJ, Masashi K. Apoptosis induction effect of curcumin and its analogs pentagamavunon- 0 and pentagamavunon- 1 on cancer cell lines. Asian J Pharm Clin Res 2017;10:5-8.

33. Opdyke DL. Monographs on fragrance raw materials: Vanillin. Food Cosmet Toxicol 1977; 15:633-8. 